\title{
Assessing the student academic workload in the learning process of a technical university
}

\section{Avaliação da carga acadêmica do aluno no processo de aprendizagem de uma universidade técnica}

\section{Evaluación de la carga de trabajo académico del estudiante en el proceso de aprendizaje de una universidad técnica}

\author{
Aygul Z. Ibatova ${ }^{1}$ \\ ${ }^{1}$ Industrial University of Tyumen, Tyumen, Russia. \\ Corresponding author: \\ Aygul Z. Ibatova \\ Email: aigoul@rambler.ru
}

Ibatova, A. Z. (2021). Assessing the student academic workload in the learning process of a technical university Revista Tempos e Espaços em Educação, 14(33), e16273. http://dx.doi.org/10.20952/revtee.v14i33.16273

\begin{abstract}
The article deals with an assessment of the students' workload influence on the academic progress in a technical university. This study was carried out at Tyumen Industrial University, the Branch of IUT in Surgut. The research participants were the first-year students of full-time and part-time departments of the "Oil and Gas Business" direction. The research was done in 2017-2018. Much attention is given to some of the consequences that first-year students have: neuropsychic stress, declining academic progress, and the quality of education. There are reasons for such a state: lack of time, a large amount of information, many classroom hours, irregular distribution of the students' workload intensity of academic disciplines in the first semester, etc. The research gives valuable information on the necessity to improve the system of students' organizational and educational activities, depending on the specific features of a technical university. This study contributes to the existing research on the impact of academic workload on the students' emotional, mental state in higher education. Specifically, it studies the volume of the freshmen's academic workload in accordance with the curriculum, which is one of the main negative factors affecting the level of mental students' performance.
\end{abstract}

Keywords: Academic. Learning. Workload. Curriculum. University.

\section{RESUMO}

O artigo trata de uma avaliação da influência da carga horária dos alunos no progresso acadêmico em uma universidade técnica. Este estudo foi realizado na Tyumen Industrial University, filial do IUT em Surgut. Os participantes da pesquisa foram os alunos do primeiro ano dos departamentos de tempo integral e meio período da direção "Negócios de Petróleo e Gás". A pesquisa foi realizada em 2017-2018. Muita atenção é dada a algumas das consequências que os alunos do primeiro ano têm: estresse neuropsíquico, declínio do progresso acadêmico e qualidade da educação. Os motivos para tal estado são: falta de tempo, grande 
quantidade de informações, muitas horas de aula, distribuição irregular da carga horária dos alunos das disciplinas do primeiro semestre, etc. A pesquisa fornece informações valiosas sobre a necessidade de aprimoramento o sistema de atividades organizacionais e educacionais dos alunos, dependendo das características específicas de uma universidade técnica. Este estudo contribui para as pesquisas existentes sobre o impacto da carga de trabalho acadêmico no estado emocional e mental dos alunos no ensino superior. Especificamente, estuda o volume da carga de trabalho acadêmico dos calouros de acordo com o currículo, que é um dos principais fatores negativos que afetam o nível de desempenho dos alunos mentais.

Palavras-chave: Acadêmico. Aprendizagem. Carga de Trabalho. Currículo. Universidade.

\section{RESUMEN}

El artículo trata de una evaluación de la influencia de la carga de trabajo de los estudiantes en el progreso académico en una universidad técnica. Este estudio se llevó a cabo en la Universidad Industrial de Tyumen, la rama de IUT en Surgut. Los participantes de la investigación fueron los estudiantes de primer año de los departamentos a tiempo completo y parcial de la dirección "Negocio de petróleo y gas". La investigación se realizó en 2017-2018. Se presta mucha atención a algunas de las consecuencias que tienen los estudiantes de primer año: estrés neuropsíquico, disminución del progreso académico y la calidad de la educación. Hay razones para tal estado: falta de tiempo, gran cantidad de información, muchas horas de clase, distribución irregular de la carga de trabajo de los estudiantes, intensidad de las disciplinas académicas en el primer semestre, etc. La investigación brinda información valiosa sobre la necesidad de mejorar el sistema de actividades organizativas y educativas de los estudiantes, en función de las características específicas de una universidad técnica. Este estudio contribuye a la investigación existente sobre el impacto de la carga de trabajo académico en el estado emocional y mental de los estudiantes en la educación superior. Específicamente, estudia el volumen de trabajo académico de los estudiantes de primer año de acuerdo con el plan de estudios, que es uno de los principales factores negativos que afectan el nivel de desempeño mental de los estudiantes.

Palabras clave: Académico. Aprendizaje, Carga de trabajo. Plan de estudios. Universidad.

\section{INTRODUCTION}

The chosen research topic is relevant today, as the influence of the educational process, the academic workload on the success of training is significant. The educational process in higher education as a system of organizational and didactic initiatives aimed at implementing the content of education at a certain level of education in training specialists is regulated by state standards. In accordance with the state standard of higher education, work programs and programs are approved at the Department of Natural Sciences and Humanities of the Branch of IUT in Surgut (Ilyinich, 2019; Ab Wahid, et al., 2020).

The latest achievements of the oil and gas industry, science, and technology should be taken into account in the work programs today. It is necessary to ensure the interconnection of specialties, indicate the interdisciplinary connection and indicate the topics reserved for students' independent study in a higher education institution when drawing up work programs.

The work programs indicate hours by the form of study, a specific list of laboratory and practical classes, the content of course projects (works), a list of primary and additional literary sources recommended to students on each topic, as well as forms of control and assessment of students' work ( Ryabtsev, et al., 2017).

Professional training involves the acquisition of theoretical knowledge by students in the basics of the oil and gas industry and specialization and development of practical skills necessary for professional activity in the field of production (Lezareva \& Lytaev, 2019).

The basic academic disciplines determine the content of professional training at the branch of IUT in Surgut: mathematics, physics, foreign language, electrical engineering, thermodynamics, etc. and academic disciplines of specialization: oil and gas geology, exploration of wells and reservoirs, collection and preparation of good products, development of oil fields, etc. Methodological and methodological development of curriculum for disciplines at the Branch of IUT 
is based on the curriculum. The curriculum includes a list of disciplines studied and the form of control, credits, the time allotted for the study of disciplines, distribution of hours by semester, duration of study by semester, etc. (Gregory \& Lodge, 2015; Hamzah et al., 2021).

The success of training in higher educational establishments and the quality of training directly depends on students' health; maintaining health requires more time and effort. Therefore, the correct academic workload distribution is necessary for successful and effective intellectual students' activity. Perception and processing of a large volume of information are not produced with a lack of time, neuropsychic stress, and performing work at night and in the evening. In such terms, students' training is rather difficult, and it also affects the mental and emotional students' state. It is necessary to distribute the academic workload according to generally accepted norms and standards to have the students' educational work as useful and productive as possible (Shuhidan et al., 2020).

The object of the research is the academic workload of students in the learning process. The subject of the research is the effective educational activity of students. Research hypothesis: we are sure that the volume of workload affects education and student performance in a higher education institution at a technical university.

This study aims to study the influence of students' workload on the quality of educational activities of students in the Surgut Branch of IUT.

Many Russian and foreign scientists have dealt with this problem.

Many teachers consider this problem from the perspective of the impact of the workload on the health of students.

So, Kovalenko \& Bykov (2016) studied the influence of the educational process on the students' well-being in a medical university. The author notes that irrational planning of the academic workload in conditions of information overload, the introduction of new disciplines, lack of time leads to depression, neuroses, and various diseases among students. The study also cited risk factors that contribute to the development of health indicators depending on the educational process's characteristics.

Abrahamyan E. \& Minasyan S. (2016) studied indicators of heart rate variability (HRV) in schoolchildren in the educational process. Scientists have identified the characteristics of HRV depending on age and the specifics of learning, and their influence depending on the workload.

Ryabtsev, Rusanov, \& Goncharova (2017) determined the university's pedagogical conditions for a successful education.

But there is also a contradictory opinion of teachers who believe that the university has an insufficient academic workload.

Ilyinich V. (2019) believes that one of the factors that negatively affect the quality of training of graduates is the insufficient mental and physical performance when studying at a university as a necessary prerequisite for the formation of knowledge and professional skills in highly qualified future graduates.

Considering studies that address the impact of workload on the quality of education, we analyzed the following.

Yukhnovich A. (2016) analyzed the ratio of the university's academic load in sufficient detail in their papers and its impact on the education quality. Teachers assume that the classroom load, which is allocated $50 \%$ of the time, does not affect the quality of education positively, as only $10 \%$ of what they hear is learned by students. Today it is necessary to understand the role of certain types of knowledge in professional activity, as their relationship and correspondence with the psychological state of a specialist, which ensures success in professional activity.

Some researchers investigated the impact of academic workload on the academic performance of the 1st year students. The authors identified a combination of specific characteristics that are inherent to this form of mental activity, namely: perception and processing 
of various information in case of lack of time, the occurrence of a state of neuropsychiatric stress, to perform a significant part of the work in the afternoon and evening. One of the University features is that students have a number of unusual problems, such as a new team and housing, distance from their hometown, and familiar environment (Kamensky \& Semenov 2019).

Lezareva T. \& Lytaev S. (2019) assert that students' academic performance depends on students' motor activity. Activation of the student's adaptive processes and learning skills is carried out due to a high level of development of motor qualities and functional reserves, which help reduce stress in the learning process.

Gregory M. \& Lodge J. (2015) point to factors that affect students' educational load, namely: academic identity and culture, correct time allocation, academic, technological potential, University policy, including funding terms. The authors also propose a model for distributing student workload.

Timchenkova S. (2018) examines the impact of workload on students' psycho-emotional state, the nature of the educational process, and the resulting effect of the change, both on the psychological and physiological levels.

Analysis of the literature on this issue shows that an important problem is the adaptation of the student to the academic workload at all stages of the pedagogical process.

In the first years, many students refuse to continue their studies, as they cannot continue their studies due to neuromuscular tension and intense academic workload. They are transferred to other universities, change their specialty in the hope of more favorable conditions. However, most universities have the same curriculum, and students again have to adapt to a new team, rules, and conditions. Technical universities try to distribute academic subjects so that students can combine many aspects of their lives. But even in this case, when studying takes up a large part of life, students cannot properly allocate their time. Sometimes universities do not distribute classes harmoniously, and teachers are home-based and independent tasks. In such cases, students experience a strong academic workload which incites health problems and moral exhaustion.

Scientists and teachers identify the main characteristics of adaptation to the educational process and workload:

- A large amount of information;

- Complex interpersonal relationships;

- Lack of physical activity;

- Mental activity associated with neuromuscular tension;

- New living conditions, food, separation from family, etc.

Bowyer K. speaks about this problem in his manuscripts.

In his papers, Bowyer K. (2012) explores the problem associated with the academic workload. The scientist is concerned that the volume of academic load contributes to the fact that students are forced to stop studying at universities, which leads to additional costs, both on the part of the student and the state. The author proposed his own model of academic load for students in Australia. This model is based on factors that affect student workload (Bowyer 2012).

Moreover, we confirm that the failure of the learning process is only a result of adaptation problems of students for training, the main problem is to prevent and prevent the development of a number of diseases that can reduce the effectiveness of the educational process, and there is the need for proper allocation of the workload at all stages of education at the university.

\section{METHODOLOGY}

The research was carried out at Tyumen Industrial University, the Surgut branch of IUT. The research participants are first-year students of full-time and part-time departments in the areas of 
"Oil and Gas Business", "Operation of transport and technological machines and complexes". The total number of participants was 147 people. The study was conducted in 2017-2018.

The purpose of this research is to study the impact of academic workload on the psychophysiological indicators of the educational process: during the school day, the school week, taking into account the features of training at a technical University.

It is necessary to conduct a study three times a week before and after classes to find out the physiological and psychometric factors. Physiological research includes evaluating students' mental and physical condition before and after training sessions.

An empirical research method in the form of questionnaires, testing, pedagogical observation, as well as a mathematical method of data processing was used.

We collected data using an empirical research method - questioning, testing, and pedagogical observation to study the pedagogical process and obtain information about the results of pedagogical observation.

According to Krivonogova A. \& Tsyplakova S. (2017), empirical methods (pedagogical experiment, analysis, synthesis, induction, deduction, analogy, etc.;

Used in pedagogical forecasting. Accordingly, we followed the pedagogical experiment and information synthesis methodology (Krivonogova \& Tsyplakova, 2017).

First-year students were involved in the experiment to obtain reliable data; first-year students are exposed to stress.

\section{RESULTS}

The educational process involves a large amount of information and requires intensive work of students at universities. The high psychosocial maladaptation of students, especially in the initial period of study especially causes concern.

Tyumen Industrial University has its own Charter and working plan, which provides for the maximum number of classes, academic hours, academic subjects, time for recreation, and exam schedule. This allows you to distribute the academic workload of students so that the learning process is better assimilated. Each university has its own maximum number of hours, but it should not exceed 12 hours a day, and the break between classes should not be more than 3 hours.

The beginning of training terms for students of all forms of education begins on September 1 and ends in accordance with the curriculum for a specific field of study. However, the academic Council can move or postpone the beginning of the academic year, but not for more than two months.

The main professional educational program of higher education provides studying the following mandatory subjects:

- General humanitarian and socio-economic sciences;

- Mathematical and General natural science;

- General professional (for a specific direction or specialty of training);

- Special.

In the branch of IUT in Surgut, the share of the disciplines mentioned above was distributed as follows on the first courses:

- Mathematical and General natural science (13\%);

- General humanitarian and socio-economic (20\%);

- General professional (34\%);

- Special (33\%).

The maximum volume of subjects studied must not exceed 50 hours a week, including all types of classes in and out of the classroom activities. For part-time (evening) education, the volume of classes in the class should be at least 10 hours a week. 
The largest volume of classroom classes in the full-time department of education should be about 27 hours per week, excluding elective classes. The number of hours is limited by the state educational standard of higher professional education.

Analysis of the training schedule at the Surgut branch of IUT in the first year showed that in the $1^{\text {st }}$ semester, the number of hours was 38 hours per week. Between lectures, there are breaks of 5,10 , and 45 minutes for lunch.

It is necessary to note there is ambiguity in the distribution of the percentage of workload load depending on the course of study. From the second year, the ratio of the load towards the blocks of General professional and special disciplines increases. For example, in the fourth year, the share of the General education block of disciplines is reduced to zero, which significantly increases the educational load's share as new types of educational activities appear: term papers, diploma work, practice, etc.

In the first courses of students of the direction "Oil and Gas business," we will present the academic workload for the discipline" Foreign language."

According to the curriculum, the discipline "Foreign language" is studied in 1-4 semesters.

Table 1. Distribution of the academic load in the discipline "Foreign language»

\begin{tabular}{cccc}
\hline FACULTY & 2016 & 2017 & 2018 \\
Oil and Gas Business & $\begin{array}{c}\text { Full time/part-time } \\
\text { training }\end{array}$ & $\begin{array}{c}\text { Full time/part-time } \\
\text { training }\end{array}$ & $\begin{array}{c}\text { Full time/part-time } \\
\text { training }\end{array}$ \\
\hline Practice classes & $173 / 40$ & $171 / 40$ & $171 / 40$ \\
\hline Independent work & $151 / 284$ & $153 / 284$ & $153 / 284$ \\
\hline
\end{tabular}

Table 1 shows that a large proportion falls on the independent study of the material. Practical classes make up $53 \%$ of the total time for full-time students. For students of the correspondence Department, the share of practical classes is only $12.3 \%$.

Students note the uneven distribution of the academic workload, as the labor intensity of individual academic subjects is not taken into account; for example, in the first semester, such complex subjects as mathematics, foreign language, physics are taught. The largest part of the classroom hours is delivered in the first semester, during the period of students' adaptation to the educational process. Moreover, for example, in a foreign language, students are forced to study independently for at least as many hours as in the classroom. The same situation applies to other items. Such a sharp and voluminous load affects the health of students.

The next questionnaire included questions about health before and after training sessions. Students participated in the survey of the 1st course. They had to answer a number of questions about their workload, academic performance, General condition after school, emotional and physical condition. 
Table 2. Results of the survey of first-year students

\begin{tabular}{ccc}
\hline Questions asked during the survey: & \multicolumn{2}{c}{$\begin{array}{c}\text { Answers } \\
\text { (in \%) }\end{array}$} \\
\cline { 2 - 3 } & Yes & No \\
\hline $\begin{array}{c}\text { 1. University performance } \\
\text { (Is there time left for additional classes, } \\
\text { extracurricular activities, work, etc.?) }\end{array}$ & $30 \%$ & $70 \%$ \\
\hline $\begin{array}{c}\text { 2. State before classes } \\
\text { (How well do you feel before the start of } \\
\text { classes?) }\end{array}$ & $55 \%$ & $45 \%$ \\
\hline $\begin{array}{c}\text { 3. State after classes } \\
\text { (Do you feel tired after studying?) }\end{array}$ & $80 \%$ & $20 \%$ \\
\hline $\begin{array}{c}\text { 4. Academic workload at the university } \\
\text { (Is there a large workload at the university?) } \\
\text { 5. Number of academic subjects } \\
\text { (Would you like to reduce the number of } \\
\text { classes and study hours?) }\end{array}$ & $70 \%$ & $30 \%$ \\
\hline
\end{tabular}

Based on Table2, Students devote $64 \%$ of their academic time to study, which indicates a responsible approach to learning, and they have to give up many activities and extracurricular activities. Students devote $36 \%$ of their time to their personal life and $12 \%$ to extracurricular activities.

We also analyzed the progress of the 1st year students from 2016-2018. Analysis of the results showed that academic performance in all subjects falls every year. In mathematics, students' academic performance decreased from 75.3 to $67.1 \%$, i.e., \pm 4.1 of the average, etc. In physics from 73 to $71 \%$; in chemistry from 83 to $78 \%$; in a foreign language from 86 to $81 \%$, i.e., in all subjects, the error was \pm 3 .

Students point out several reasons for this: many students experience a lack of time due to intensive study and feel overloaded. Most of them would like to reduce the number of academic subjects and have a more optimal study schedule. Sometimes study begins after lunch or in the evening, and because of this, not everyone can combine some clubs and work. There are some reasons for this: mental activity is at its highest level in the morning than in the afternoon. All these factors affect both academic performance and health. The state achieves the highest indicators after classes. Students experience severe stress after studying and want to reduce the number of academic subjects. The students show the lowest performance indicators at the university, which means that students do not cope with the academic workload.

\section{DISCUSSION}

In addition to the physical overstrain of the first-year students, it is necessary to note the loads associated with frequent informational and emotional overloads, stressful situations, which is a problem for freshmen. In this regard, it becomes promising to study the connection between the choice of strategies for overcoming difficult situations along motivational sources.

Having studied the approaches of different teachers and scientists to the problem of overcoming stress, we believe that in the conditions of training in the first year, students' psychological adaptation occurs mainly through two mechanisms: psychological defense and coping mechanisms, i.e., adaptive behavior or a way of psychological coping with stress.

There are many approaches to the problem of coping with stress; summarizing the definitions and types of coping with stress, there are three main options for coping behavior in stressful situations: coping aimed at stimulus or coping aimed at emotional response; coping aimed at evaluation. Motivation includes all kinds of motivations for human behavior. The motive is a 
conscious element of motivation. The period of adaptation of first-year students is associated with the development of positive motivation and interest in educational and cognitive activities.

Many researchers are investigating the issue of the formation of incentives for educational activity (Bakshaeva \& Verbicki 2017). In psychological research, scientists distinguish: cognitive; social (desire to prepare for a future profession); moral (get a good grade); motives of communication.

Taking into account the characteristics of the motives proposed in pedagogy, and also, taking into account the specifics of the process we are studying, to characterize the motivation of freshmen in the preparation process, we identified the following motives: communicative (includes the interest of communication in the lesson, since the language serves as a means of meeting extracurricular interests); social (includes respect for teachers and fellow students, the desire to avoid condemnation from parents and fellow students for poor performance); pragmatic (includes professional motives, the desire to become a highly qualified specialist); cognitive (interested in the content of the subject, the form of organization of classes and teaching methods, interest in learning new things).

The motives of educational and cognitive activity have several meanings: being a product of personality formation, they act at the same time as a factor in its further development; have a general stimulating effect on the course of thought processes, become a source of intellectual activity; mobilize creative forces to find and solve cognitive tasks; being the most important internal condition for development, they generate the desire for self-education; serve as an indicator of important personality traits - conscientiousness, hard work; the breadth and stability of its cognitive processes.

In the context of this educational process, communicative motives acquire special significance, their level often does not depend on the organization of the educational process (some people are talkative and taciturn), but they act as a background for the development of situational motives, the level of which is determined when situations of verbal communication are created, from the used material, etc. It is the degree of formation of these types of motivation and interest that characterizes the degree of formation of students' readiness for educational and cognitive activity. We also highlight incentives that contribute to the development of positive motivation, professional interest in educational activities. These incentives include: creating a positive emotional atmosphere; use of methods of group, individual work; the correct distribution of the teaching load; the formation of the schedule of classes taking into account the health-saving technologies, etc.

Determining the level of formation of certain types of motives is a rather difficult task. Therefore, we used such a method as expert research. To assess the weight of each group of motives and interest in educational and cognitive activities, a group of experts was created, consisting of students of IUT branch in Surgut, the Yelabuga Pedagogical Institute of Kazan Federal University in the amount of 50 people. After reviewing the motives we identified, the experts determined the weight of each group of motives. The analysis of the expert research results showed that the most significant in the process of professional training are social and cognitive motives. Other motives communicative and pragmatic, according to experts, also play an important role in the pedagogical process, but to a lesser extent affect the adaptation of students to the educational process in the first year.

On the basis of the results of the expert research, we have identified three levels of the formation of motives for educational activity: high, medium, and low.

High level - the student's activity in the process of professional training is due to all types of motivation. The student is positively disposed towards this type of activity in the educational process, shows a steady interest in studying at a higher educational institution. 
The middle level - the student's activity in the process of preparing for the implementation of educational activities is characterized by pragmatic motives. The attitude towards future professional activity and the educational process is neutral. Interest in the implementation of the activities of communication in a foreign language in their professional activities has an episodic character. Activity in the educational process is low.

Low level - the student's activity in educational and cognitive processes is conditioned by cognitive (interested in forms and methods of teaching) and social motives. The student is negatively disposed towards this type of activity in an educational institution; there is no interest in learning; participation in the educational process is low.

To determine the degree of stability of interest, the nature of the attitude, and the prevalence of types of motivation to educational and cognitive activity, we have developed two questionnaires, which to one degree or another reflect all the types of motivation we have identified for learning, interest, and attitude to learning activities in a higher institution.

The analysis of motives showed that at the initial stage of training, the most common are social motives $-40 \%$, cognitive $-38 \%$, communicative $-16 \%$, pragmatic ones are present much less - $6 \%$. We believe that such results are because students do not fully realize the importance of educational activities for the future professional sphere, do not see the prospects for further education, and the possibility of applying the knowledge they acquire.

Senior students are dominated by high intrinsic motivation, motivation for learning activities aimed at becoming a qualified specialist, so they try to solve problems on their own and not expect help from a curator, parents, or someone else. In the educational process, they try to correctly distribute the teaching load, take responsibility for the work performed, solve the problem, and avoid it. Hypothetically, we can say that internally motivated students use different coping strategies. Senior students are sociable and successful even with an intensive academic load.

As for the ways to overcome the stress associated with the workload, it can be noted that, when stimulating and motivating in learning activities, freshmen more often develop a strategy of focusing on solving problems, resorting to fellow students or teachers' help. Students often use the strategy of avoidance, so they are more unbalanced during an intense study load; students can avoid communicative relationships with classmates, which will be expressed in lack of communication and low emotionality. Such a difference in the ways of coping with stress depends, in our opinion, on the type of motivation, since intensive study load negatively affects with a low internal indicator, that is, there is a danger of mental development of students of a technical university who are not capable of reflecting on their mistakes. Moreover, for each coping strategy, various motivational sources act as an integrating basis for its formation.

Suppose first-year students are not motivated, not encouraged with points, grades. In that case, they begin to avoid stressful situations, do not solve them, and focus on other people's opinions. At the same time, senior students are dominated by intrinsic motivation and problemsolving strategies.

In order to optimize the educational process at the higher educational institution of the TIU branch in Surgut, we consider it necessary to introduce several strategies for coping with the stress of freshmen:

1. Adequate perception of the academic load, the adaptive period of study in the first year, that is, a sufficiently accurate assessment of actions and intentions, not distorted by personal preferences.

2. In the first year, students need to look for solutions through internal personal resources, mutual concessions and look for intermediate solutions to the problem.

3. Students need to conduct a thorough analysis of the study load and personal capabilities to increase the effectiveness of their studies, correct the shortcomings that interfere with the full- 
fledged educational process, the performance of their duties, and the organization of the school day.

4. Students in the first year should be ready for an open dialogue with fellow students and teachers. The main goal of the dialogue is understanding and mutual understanding. In this vein, the dialogue is the only way to unite people at all its levels, where the main condition is the recognition of the right to exist, opinion, a different worldview, language, logic, rules of communication, culture, where the personality is active, its needs for self-improvement are considered not in isolation but develop only in the context of relationships with other people, built on the principle of dialogue. On the part of the teacher, it is necessary to build the lesson in the form of communication, is an active participant in the dialogue, shows personal interest in the indicated problem - all this involves increasing the motivation of the problem of communication among students, enhancing personal representation in the student's dialogue and, as a result, developing the ability for dialogical perception: understanding the role of dialogue in the context of its holistic development; knowledge of the "language" of a given subject and ways of interacting with it; using the experience of interaction as a "material" for self-construction, self-improvement. Such work with students allows us to solve several problems when adapting freshmen:

- Formation of the ability to identify contradictions between one's own views and the point of view of another;

- Tolerant perception of the interlocutor, the ability to critically analyze situations; the ability to emotionally react and interact with each other;

- The ability to put forward and argue hypotheses;

- The formation of students' ability to reflect, a sense of responsibility for the course and result of the dialogue;

- The formation of systemic knowledge on the subject, the ability to independently creatively identify the problem in the educational material;

- Formation of skills of intercultural interaction based on the "dialogue of cultures," taking into account the national characteristics of the interlocutors.

Acknowledgments: Not applied.

\section{CONCLUSIONS}

Thus, the following practical conclusions can be drawn:

1) Most students experience an intense academic workload and would like to reduce the number of study hours. This may indicate that students do not allocate their time efficiently as an unusual environment and a new learning system affect the neuropsychological and emotional state and the workload of students.

2) Some students are disappointed in their chosen profession due to overwork and heavy academic workload. The data shows that some were disappointed in the chosen specialty after the first session. Students note a decrease of interest in subjects; there are doubts about their professional choice's correctness. Most students are clarifying their ideas about the chosen specialty. Therefore, there is a need to reduce the number of training hours in the first semester for further more effective training.

3) Students, due to intensive study, do not have time to engage in extracurricular activities, clubs, physical culture, and experience health problems.

4) Many students cannot prioritize their assigned tasks and use their personal time.

Therefore, to effectively design the educational process, it is necessary to improve the system of organizational and educational activities based on research data. All measures should be aimed at maintaining the health of students, the correct redistribution of the academic load during 
the first year at the university in the direction of General subjects, electives, and other activities, and depending on the specifics of a Technical University.

Stress risk factors include Yakovlev, Apokina, \& Litovchenko (2020) stress pedagogical tactics; intensification of the educational process; inconsistency of teaching methods and technologies with the age and functional capabilities of students; irrational organization of educational activities; functional illiteracy of the teacher in matters of health protection and promotion; lack of a system of work on the formation of the value of health and a healthy lifestyle (including prevention of bad habits, sex education and sex education, insufficient use of physical education and sports, etc.).

Therefore, for the effective design of the educational process, it is necessary to improve the system of organizational and educational activities in a higher educational institution, based on research data. All measures should be aimed at maintaining the health of students, the correct redistribution of the academic load in the first year at the university towards general education subjects, electives, and other events, depending on the specifics of the technical university.

Authors' Contributions: Aygul Z. Ibatova: conception and design, acquisition of data, analysis and interpretation of data, drafting the article, critical review of important intellectual content. All authors have read and approved the final version of the manuscript.

Ethics Approval: Not applicable.

Acknowledgments: Not applicable.

\section{REFERENCES}

Ab Wahid, M., Lee, W. K., \& Baharudin, F. (2020). Implementing project-based learning for sustainability management course at postgraduate level. Asian Journal of University Education, 16(2), 84-92.

Abrahamyan, E. T., \& Minasyan, S. M. (2016). Corrective influence of aromatherapy on indicators of rate variability of students during examination stress. Hygiene and Sanitation, 95 (6), 563-568.

Bakshaeva, N., \& Verbicki, A. (2017). Psychology of student motivations. Liters.

Bowyer, K. (2012). A model of student workload. Journal of Higher Education Policy and Management, 34(3), $239-258$.

Gorelova, A.V., Simasheva, V. V., \& Ivanova, N. L. (2018). Analysis of the results of a survey on the health status of correspondence students. In Actual problems of scientific knowledge. New technologies of the fuel and energy complex-2018, 263-266.

Gregory, M. S. J., \& Lodge, J. M. (2015). Academic workload: the silent barrier to the implementation of technologyenhanced learning strategies in higher education. Distance education, 36(2), 210-230.

Hamzah, F., Phong, S. Y., Sharifudin, M. A. S., Zain, Z. M., \& Rahim, M. (2021). Exploring Students' Readiness on English Language Blended Learning. Asian Journal of University Education, 16(4), 161-170.

Ilyinich, V.I. (2019). Professional applied physical training of university students (scientific, methodological and organizational foundations).

Kamensky, D.A., \& Semenov, S.V. (2019). The impact of sleep patterns on student performance and physical activity. In collection of selected articles on the materials of scientific conferences of the State Research Institute "National Development", 190-192.

Kovalenko, A. N., \& Bykov, E. V. (2016). Goals and objectives of the program "Monitoring the state of health of students of the University of Physical Education. Bulletin of the Chelyabinsk State Pedagogical University, 9, 3485 3490

Krivonogova, A.S., \& Tsyplakova, S.A. (2017). Research methods of vocational education problems. Bulletin of Minin University, 1(18).

Lezareva, T.A., \& Lytaev, S.A. (2019). On the effectiveness of the mechanisms of psychophysiological adaptation in the dynamics of the educational process. Pediatrician, 10 (6), 62-67. 
Ryabtsev, S.M., Rusanov, V.P., \& Goncharova, M.S. (2017). Health-preserving education in the system of professional training of specialists at the university. Modern problems of science and education, 3, 81-81.

Shuhidan, S. M., Majid, M. A., Shuhidan, S. M., Anwar, N., \& Abd Hakim, A. A. (2020). School Resource Center and Students' Civilization in Digital Age. Asian Journal of University Education (AJUE), 16(4), 190-199.

Timchenkova, S.P. (2018). The influence of intellectual load on the emotional state of students. Science and education issues, 6(18), 121-129.

Yakovlev, B. P., Apokina, L. Y., \& Litovchenko, O. G. (2020). Mental Load and Level of Mental Working Capacity of Senior Graduates in Conditions of Specialized Education. International Journal of Humanities and Aesthetic Sciences, 5(3), e10582.

Yukhnovich, A.S. (2016). Development of methodological support for the discipline "Introduction to professional pedagogical activity (Doctoral dissertation, Siberian Federal University).

Received: 4 May 2021 | Accepted: 2 August 2021 | Published: 25 August 2021

This is an Open Access article distributed under the terms of the Creative Commons Attribution License, which permits unrestricted use, distribution, and reproduction in any medium, provided the original work is properly cited. 